\title{
Anti-inflammatory role of Fetuin-A in Injury and Infection
}

\author{
Haichao Wang and Andrew E. Sama \\ Department of Emergency Medicine, North Shore University Hospital, The Hofstra North Shore - \\ LIJ School of Medicine at the Hofstra University, Manhasset, NY 11030, USA
}

\begin{abstract}
Infection and injury are two seemingly unrelated processes that often converge on common innate inflammatory responses mediated by pathogen- or damage-associated molecular patterns (PAMPs or DAMPs). If dysregulated, an excessive inflammation manifested by the overproduction and release of proinflammatory mediators (e.g., TNF, IFN- $\gamma$, and HMGB1) may adversely lead to many pathogenic consequences. As a counter-regulatory mechanism, the liver strategically reprioritizes the synthesis and systemic release of acute phase proteins (APP) including the fetuin-A (also termed alpha-2-HS-glycoprotein for the human homologue). Fetuin-A is divergently regulated by different proinflammatory mediators, and functions as a positive or negative APP in injury and infection. It not only facilitates anti-inflammatory actions of cationic polyamines (e.g., spermine), but also directly inhibits PAMP-induced HMGB1 release by innate immune cells. Peripheral administration of fetuin-A promotes a short-term reduction of cerebral ischemic injury, but confers a long-lasting protection against lethal endotoxemia. Furthermore, delayed administration of fetuin-A rescues mice from lethal sepsis even when the first dose is given 24 hours post the onset of disease. Collectively, these findings have reinforced an essential role for fetuin-A in counter-regulating injury- or infection-elicited inflammatory responses.
\end{abstract}

\section{Keywords}

Innate immune cells; PAMP; DAMP; acute phase protein; HMGB1; endotoxemia; sepsis; cerebral ischemic injury

\begin{abstract}
Infection and injury, seemingly unrelated conditions, converge on a common process inflammation, which is mediated partly by innate immune cells including macrophages and monocytes. These innate immune cells are equipped with pattern recognition receptors (such as TLR2, TLR4, and TLR9) [1-3] that can recognize both pathogen- and damage-associated molecular patterns (PAMPs, such as endotoxin, and DAMPs, such as HMGB1) [4-7]. In response to various PAMPs or DAMPs, innate immune cells release proinflammatory cytokines (such as TNF, IL-1, IFN- $\gamma$ or HMGB1) to mount inflammatory responses. If dysregulated, an uncontrolled inflammation may adversely lead to detrimental consequences. In this review, we summarize emerging evidence to support fetuin-A as an acute phase protein capable of attenuating infection- and injury-elicited inflammatory responses.
\end{abstract}

*Address correspondence to: Dr. Haichao Wang, Department of Emergency Medicine, North Shore University Hospital, North ShoreLIJ Health System, 350 Community Drive, Manhasset, NY 11030, USA; Tel. (516)562-2823; Fax: (516)562-1022; hwang@ nshs.edu. 


\section{PATHOGENIC ROLES OF DYSREGULATED INFLAMMATION IN INFECTION AND INJURY}

\subsection{Bacterial Infection}

As a syndrome of dysregulated systemic inflammation to a microbial infection, sepsis is partly attributable to the excessive production of various proinflammatory mediators. In animal models of endotoxemia and bacteremia, overexpression of early proinflammatory cytokines, including TNF [8], interleukin (IL)-1 [9], interferon (IFN)- $\gamma$ [10], individually or in combination, contribute to the pathogenesis of lethal systemic inflammation (Figure 1). However, the therapeutic windows for these early mediators are relatively narrow, prompting the search for other "late" pro-inflammatory mediators that may offer better therapeutic opportunities. A decade ago, we made the seminal finding that high mobility group box-1 (HMGB1) was released from macrophages or monocytes in response to exogenous PAMPs (e.g., endotoxin or CpG-DNA) $[7,11]$ or endogenous cytokines (e.g., TNF or IFN- $\gamma$ ) $[7,12]$. In addition, HMGB 1 can be passively leaked by necrotic cells [13,14], thereby functioning as a damage-associated molecular pattern (DAMP). Upon binding to the receptor for advanced glycation end products (RAGE), TLR2 or TLR4 [1517], HMGB1 induces the expression of various cytokines, chemokines, and adhesion molecules [15,16,18-24]. Consequently, extracellular HMGB1 functions as an alarmin signal to alert, recruit and activate innate immune cells [4,25-28], thereby sustaining rigorous and potentially injurious lethal systemic inflammation.

In animal models of endotoxemia and sepsis (induced by cecal ligation and puncture, CLP), circulating HMGB1 increased to plateau levels between 24-36 h [7,29]. This late appearance precedes the onset of animal lethality, and distinguishes HMGB1 from TNF and other early cytokines [30]. The pathogenic role of HMGB1 was inferred from the observations that HMGB1-neutralizing antibodies [7,29,31] and inhibitors (e.g., tanshinones, ethyl pyruvate, nicotine, stearoyl lysophosphatidylcholine, epigallocatechin-3gallate, nicotine, choline, GTS-21, and spermine) [7,32-40] confer protection against lethal endotoxemia and sepsis, even when the first dose of these antidotes was given $24 \mathrm{~h}$ after CLP - a time point when mice had developed clear signs of sepsis. Conversely, administration of exogenous HMGB1 to mice recapitulated clinical manifestations of sepsis, including fever [41], derangement of intestinal barrier function [42] and tissue injury [4346]. Collectively, these data establish HMGB1 as a critical "late" mediator of sepsis with a wider therapeutic window (Figure 1) [30,47-49].

\subsection{Cerebral Ischemic Injury}

Cerebral ischemic injury (stroke) consists of two stages: i) primary tissue damage in the ischemic core that is mediated by tissue ion $\left(\mathrm{Ca}^{2+}\right.$ and $\left.\mathrm{Na}^{+}\right)$overload [50] and excitotoxicity [51]; and ii) secondary tissue injury in the surrounding penumbra that is mediated by proinflammatory cytokines (Figure 2) [52]. Within seconds to minutes after cerebral ischemia, decreased ATP production leads to failure of the $\mathrm{Na}^{+} / \mathrm{K}^{+}$-ATPase pump, disruption of membrane potentials, influx of sodium and calcium, and subsequent release of excitatory amino acids (such as glutamate). Engagement of glutamate with the ionotropic Nmethyl-D-aspartate receptor (NMDA) leads to $\mathrm{Ca}^{2+}$ influx and activation of damaging proteases (e.g., phospholipase $\mathrm{A}_{2}$, nitric oxide synthase, endonucleases, and calpain) that compromise the functional and structural integrity of neuronal cells within 20-60 minutes. Early-stage therapeutics that block ion $\left(\mathrm{Na}^{+}\right.$and $\left.\mathrm{Ca}^{2+}\right)$ channels [50] and glutamate receptors [53] have failed in clinical trials, partly because of the impracticalities of administering such drugs in a timely fashion. These failures have prompted the search for other downstream targets that also contribute to the pathogenesis of ischemic injury. 
Outside of the ischemic core where cells are destined to die are penumbral zones where brain cell death continues slowly for hours and even days after the onset of ischemia. This progressive expansion of cell death in the penumbra (i.e., secondary injury) is mediated by ischemia-elicited inflammatory responses that are orchestrated by both centrally- and peripherally-derived immune cells (Figure 2). For instance, microglia and neurons become activated to produce TNF and other cytokines within a few hours [54,55]. Subsequently, polymorphonuclear cells infiltrate into the ischemic brain tissue within 12-48 hours [56], followed by an influx of monocytes and macrophages over a period of one to several days. Many pro-inflammatory cytokines (e.g., TNF and IL-1) contribute to cerebral ischemic injury [57,58], because inhibition of their production [59,60] or activity $[59,61,62]$ confers protection against cerebral ischemic injury. In addition, HMGB1, can be passively released from the ischemic core, and spilled into the surrounding periphery [63]. In the penumbra, it may amplify a potentially injurious inflammatory response by inducing various cytokines, chemokines, tissue factor and adhesion molecules (Figure 2) [4,22,23]. Indeed, HMGB1specific neutralizing antibodies and antagonists (e.g., the A box) have been proven protective [64-66], supporting a pathogenic role for HMGB1 in ischemic injury.

\section{ENDOGENOUS ANTI-INFLAMMATORY MECHANISMS}

Mammals have evolved multiple anti-inflammatory mechanisms to counter-regulate potentially injurious inflammatory responses. For instance, the central nervous system can directly and rapidly attenuate bacterial endotoxin-induced release of TNF through efferent vagus nerve signals to tissue-resident $T$ cells [67] and macrophages [68]. This effect is mediated by acetylcholine, the principle neurotransmitter of the vagus nerve, via nicotinic cholinergic receptors (such as the alpha-7 nAChR) [36,68,69]. Physical (electrical or mechanical) stimulation of the vagus nerve [36,70] reduced serum HMGB1 levels, and consequently improved survival in animal models of sepsis [70]. Similarly, a number of cholinergic chemical agonists (including nicotine, choline, GTS-21, and PHA568487) also conferred protection against lethal endotoxemia, bacteremia, and sepsis partly by attenuating HMGB1 release $[36,38,39,71]$. Taken together, these findings have suggested an important role of the central nervous system in the counter-regulation of peripheral inflammatory response.

At the sites of infection, various PAMPs also induce the production of many antiinflammatory cytokines (e.g. IL-10, IL-4 and TGF- $\beta$ ), which participate in the downregulation of the local inflammatory response [72-74]. As another local counter-regulatory mechanism, a ubiquitous biogenic molecule, spermine, can be passively released by injured cells [75], and thus accumulates at the sites of infection or injury. It effectively attenuates the synthesis and release of various pro-inflammatory cytokines (e.g. TNF, IL-1, MIP-1) from activated macrophages and monocytes [76-79]. Furthemore, the anti-inflammatory effects of spermine are dependent upon the availability of a ubiquitous protein, fetuin-A. That is, spermine fails to inactivate macrophage/monocytes if these cells are deprived of fetuin-A by serum-starvation, or addition of specific fetuin-A-neutralizing antibodies [80]. In contrast, co-addition of highly purified fetuin-A significantly enhances the antiinflammatory activity of spermine [80], supporting an important role of fetuin-A in the regulation of the innate immune responses [76,79,81].

\section{FETUIN-A AS AN ACUTE PHASE PROTEIN (APP)}

In response to infection and injury, the liver strategically re-prioritizes the synthesis and systemic release of a group of proteins collectively termed "acute phase proteins" (APPs), whose plasma concentrations are increased ("positive APPs") or decreased ("negative APPs") during inflammation. For instance, fetuin-A, also known as the alpha-2-HS- 
glycoprotein for the human homologue [82], was first characterized as a major plasma protein in the fetus [83]. During fetal development, it is expressed in many organs such as the liver, kidney, gastrointestinal tract, skin and brain [84-87]. In adults however, fetuin-A is produced primarily by the liver, and its synthesis is divergently regulated in response to injury or infection, classifying it as a negative or positive APP.

\subsection{Fetuin-A as a Negative APP in Infection}

The hepatic expression of fetuin- $\mathrm{A}$ is negatively regulated by several proinflammatory cytokines such as TNF, IL-1, IL-6 and IFN- $\gamma$ (Figure 1) [88,89]. For instance, at concentrations as low as $10-50 \mathrm{ng} / \mathrm{ml}$, IFN- $\gamma$ reduced fetuin-A expression levels by $>50$ $70 \%$ in human hepatoma HepG2 cells [89]. In contrast, HMGB1 $(1 \mu \mathrm{g} / \mathrm{ml})$ elevated hepatic fetuin-A expression levels by $2-3$ folds, suggesting that different cytokines divergently regulate hepatic fetuin-A expression (Figure 1). In animal models of endotoxemia and sepsis (induced by cecal ligation and puncture, CLP), circulating fetuin-A levels were decreased in a time-dependent fashion, starting between 2-6 h, reaching a nadir (with maximal reduction by $50-60 \%$ ) around $24-48 \mathrm{~h}$. Afterwards, fetuin-A levels started to increase, returning towards basal levels approximately $72 \mathrm{~h}$ post endotoxemia or sepsis, supporting fetuin-A as a negative APP in animal models of lethal endotoxemia and sepsis [89]. In agreement with the capacities of early proinflammatory cytokines (TNF, IL-6, and IFN- $\gamma$ ) in inhibiting fetuin-A expression $[88,89]$, we found that the genetic disruption of IFN- $\gamma$ expression led to an impairment of endotoxin-mediated down-regulation of fetuin-A expression [89]. It is thus possible that early cytokines (such as TNF and IFN- $\gamma$ ) negatively reduce circulating fetuinA levels during an early stage of endotoxemia or sepsis; whereas late-acting mediators (e.g., HMGB1) serve as a positive regulator to restore circulating fetuin-A levels at a late stage of these inflammatory diseases.

In patients with other inflammatory diseases such as pancreatitis [90], chronic kidney diseases [91], and rheumatoid arthritis [92], serum fetuin A levels were also decreased by 20-30\%. In these patients, circulating fetuin-A levels negatively correlated with levels of cytokines (such as IL-6) [90], and associated with increased mortality rates [91]. Collectively, these observations classify fetuin-A as a negative APP during infection or other inflammatory illness.

\subsection{Fetuin-A as a Positive APP in Injury}

Clinically, plasma fetuin-A levels were paradoxically elevated in patients with cerebral ischemic injury (stroke) $[93,94]$. The magnitude of fetuin-A elevation positively correlated with an increase in LDL-cholesterol levels and risk of cardiovascular disorders [93]. Following traumatic injury, serum fetuin-A levels were increased up to 10-folds in cattle [95], suggesting fetuin-A as a positive APP in response to injury. In light of the findings that HMGB 1 can be passively leaked from injured cells [96] and function as an early mediator of traumatic injury [97-101], it is plausible that HMGB1 may contribute to the up-regulation of hepatic fetuin-A expression during injury.

In an animal model of focal cerebral ischemia (i.e., permanent middle cerebral artery occlusion, MCAo), fetuin-A levels in the ischemic brain tissue were elevated in a timedependent manner, starting between 2-6 h, peaking around $24-48 \mathrm{~h}$, and returning towards baseline at $72 \mathrm{~h}$ post MCAo [102]. This dynamic increase in cerebral fetuin-A levels parallels with the transient elevation of the blood-brain barrier (BBB) permeability [103], suggesting that circulating fetuin-A can gain entry across the BBB into the ischemic brain tissue (Figure 2). This possibility was supported by the observation that peripherally (intravenously) administered FITC-labeled fetuin-A destined to the ischemic brain region at $24 \mathrm{~h}$ after MCAo [102]. 


\section{FETUIN-A AS AN ANTI-INFLAMMATORY PROTEIN}

Despite its abundance, the functions of fetuin-A remain poorly understood. A wide range of biological functions have been proposed for fetuin-A based on its structural similarities to other proteins or physical interactions with biogenic molecules. For instance, fetuin-A shares amino acid sequence homology to type II TGF- $\beta$ receptors [104], and has been proposed as an inhibitor of the TGF- $\beta$ signaling pathway. Similarly, fetuin-A exhibits amino acid sequence similarity to insulin receptor tyrosine kinases [105,106], and can bind to the insulin receptor, thereby inactivating (rather than activating, as in the case for insulin) the receptor tyrosine kinase [107]. This may partly explain why higher fetuin-A levels were associated with insulin resistance in some patients with type 2 diabetes [108]. As a glycoprotein, fetuinA carries two $\mathrm{N}$-linked and three $\mathrm{O}$-linked oligosaccharide chains that terminate with sialic acid residues, enabling the binding of cationic $\mathrm{Ca}^{2+}$ ions. Accordingly, fetuin-A has been proposed as an endogenous inhibitor of pathological mineralization or calcification in soft tissues [109-111]. Specifically, fetuin-A forms protein-mineral colloids with calcium and phosphate [112-114], thereby preventing uncontrolled mineralization that may otherwise occur under pathological conditions [115].

As aforementioned, fetuin-A also functions as an opsonin for cationic spermine, and its availability to immune cells may be critical for regulating the innate immune response [81]. Indeed, levels of fetuin-A in macrophage cultures was decreased by $40 \%$ after stimulation with LPS (100 ng/ml, $2 \mathrm{~h}$ ). Supplementation of LPS-stimulated macrophages with fetuin-A $(100 \mu \mathrm{g} / \mathrm{ml})$ conversely elevated cellular fetuin-A levels by 30-50\% [116], confirming the notion that macrophages can 'adopt" fetuin-A from the environment [81]. Intriguingly, exogenously administered fetuin-A was predominantly localized in LC3-containing cytoplasmic vesicles - possibly autophagosomes or amphisomes - in LPS-stimulated macrophages [116]. At higher concentrations (e.g., $3.5 \mathrm{mg} / \mathrm{ml}$ ), even crude fetuin-A (> 98\%) can almost completely abrogated endotoxin-induced release of IL-1 and nitric oxide in macrophage cultures [117]. Following gel filtration and ion-exchange chromatography, the highly purified fetuin-A almost completely abrogated IFN- $\boldsymbol{\gamma}$ - or LPS-induced HMGB1 release even when given at relative lower doses (e.g., $100 \mu \mathrm{g} / \mathrm{ml}$ ) [89], suggesting fetuin-A as an effective anti-inflammatory APP.

\section{THERAPEUTIC POTENTIAL OF ANTI-INFLAMMATORY AGENTS}

Given the anti-inflammatory properties of spermine and fetuin-A, we have evaluated their therapeutic potential in several animal models of local and systemic inflammation.

\subsection{Carrageenan-induced Paw Edema}

Local administration of spermine directly into the carrageenan-injected paw dosedependently inhibited the development of edema, with a maximally reduction of footpad swelling by $\sim 50 \%$ [76]. Similarly, intraperitoneal administration of fetuin-A (5 to $500 \mathrm{mg} /$ $\mathrm{kg}$ ) dose-dependently attenuated the development of paw edema [118]. When the sialic acid residues were removed by neuraminidase, the resultant asialofetuin- $\mathrm{A}$ failed to potentiate the anti-inflammatory activities of spermine [80], and similarly failed to attenuate carrageenaninduced TNF production in vivo [118], suggesting the requirement of sialic acid moieties for its anti-inflammatory activities. In contrast, administration of fetuin-A-neutralizing antibodies abolished fetuin-A-mediated inhibition of paw edema, indicating an essential role of fetuin-A in counter-regulating inflammatory responses.

\subsection{Cerebral Ischemic Injury}

During cerebral ischemic injury, spermine may be protective by inhibiting the expression of proinflammatory cytokines $[28,76,77,79,119,120]$ and scavenging cytotoxic free radicals 
(Figure 3) [121,122]. At higher (millimolar) concentrations, spermine is also neuroprotective by directly binding and blocking the NMDA receptor $[123,124]$. On the other hand, spermine can be enzymatically converted by polyamine oxidases into cytotoxic metabolites (e.g., 3-aminopropanal) [125], which readily spreads and mediates direct cytotoxicities [125]. Furthermore, at low (micromolar) concentrations, spermine activates the NMDA receptor $[124,126]$, thereby augmenting glutamate-mediated neurotoxicity by overactivating $\mathrm{Ca}^{2+}$ fluxes and disturbances of the calcium homeostasis (Figure 3). During cerebral ischemia, brain spermine levels are decreased [127], owing largely to an accompanying increase in the enzymatic activity of brain polyamine oxidase [125]. The loss of spermine consequently tilts the balance towards neurotoxicity through activating the NMDA receptor, and increasing susceptibility to oxidative stress as well as excessive inflammatory response.

As mentioned earlier, cerebral ischemia induces a transient (5-24 h) elevation of the BBB permeability [103], which allows temporal entry of circulating fetuin-A across the BBB into the ischemic brain tissue. Consistently, peripheral administration of fetuin-A promoted a short-term protection against cerebral ischemic injury [102]. Given the aforementioned pathogenic roles of $\mathrm{Ca}^{2+}$ and spermine in cerebral ischemia, as well as the capacity of fetuin- $\mathrm{A}$ in binding $\mathrm{Ca}^{2+}$ and spermine [80,112], it is also possible that fetuin-A confers protection by caging these toxic cationic molecules [51,125], thereby depriving them from damaging enzymes (such as $\mathrm{Ca}^{2+}$-dependent proteases and polyamine oxidase).

Furthermore, the fetuin-A-mediated protection is associated with a reduction of ischemiaelicited HMGB1 leakage from the ischemic core, and an inhibition of expression of proinflammatory cytokines (e.g., TNF) in the penumbra (Figure 2) [102], suggesting that fetuin-A confers protection partly by attenuating early inflammatory responses. The fetuinA-mediated neuroprotection was not long-lasting, and gradually diminished at a later stage (e.g., 7 days post MCAo). It is possible that the restore of BBB function at a late stage ( 3 days after MCAo) limits subsequent fetuin-A extravasation, thereby diminishing fetuin-Amediated long-lasting protective effects.

\subsection{Endotoxemia and Sepsis}

Despite the anti-inflammatory activities of spermine in vitro [76,128], spermine did not confer protection against lethal endotoxemia. However, it promoted a dose-dependent protection against lethal sepsis when given at relative lower doses $(1-10 \mathrm{mg} / \mathrm{kg})$. This protection was associated with a significant attenuation of systemic accumulation of HMGB1 and other cytokines (e.g., IL-6, KC, MCP-1, MIP-2, TIMP-1, sTNFRI and sTNFRII) [128]. At a higher dose (100 mg/kg), however, spermine decreased animal survival rates from $58 \%$ to $38 \%$ at $48 \mathrm{~h}$ post CLP, and further decreasing it to $0 \%$ at $72 \mathrm{~h}$ post CLP. It is not yet known whether spermine is enzymatically converted by polyamine oxidases into cytotoxic metabolites (e.g., 3-aminopropanal), thereby exerting these potentially toxic effects.

In contrast to the limited efficacy of spermine, fetuin-A exhibits a greater therapeutic potential in animal models of lethal systemic inflammatory diseases. Administration of fetuin-A (20-100 mg/kg) provided a dose-dependent protection against lethal endotoxemia. Furthermore, delayed administration of fetuin-A ( $20-100 \mathrm{mg} / \mathrm{kg})$, beginning $24 \mathrm{~h}$ after the onset of sepsis and followed by an additional dose at $48 \mathrm{~h}$ post CLP, significantly increased long-term animal survival rates from $45 \%$ to $90 \%$ [89]. The integral role of fetuin-A in host defense against lethal systemic inflammation was supported by the observations that fetuinA-deficient C57BL/6J mice were more susceptible to lethal endotoxemic or septic insult than sex- and body-matched (male, 27-29 g) wild-type C57BL/6J mice [102].

It now appears that fetuin-A serves as a negative regulator of HMGB1 release during lethal endotoxemia or sepsis (Figure 1). On one hand, the time-dependent decrease of circulating 
fetuin-A levels was paralleled by the contrast increase of serum HMGB1 levels in animal models of endotoxemia [7] or sepsis [29]. On the other hand, disruption of fetuin-A expression led to greater elevation of serum HMGB1 levels [89]; whereas supplementation of fetuin-A resulted in significant protection by reducing circulating HMGB1 levels [89]. The mechanisms underlying fetuin-A-mediated suppression of HMGB1 release remains poorly understood. At the concentrations $(100 \mu \mathrm{g} / \mathrm{ml})$ that fetuin-A attenuated LPS-induced HMGB1 release, fetuin-A stimulated autophagy and impaired LPS-induced elevation of cytoplasmic and nuclear HMGB1 levels [89]. It is not yet known whether fetuin-A, like other HMGB1 inhibitors (such as Green tea epigallocatechin gallate, EGCG) [129], reduces cytoplasmic HMGB1 levels by stimulating its degradation in an autophagy-dependent fashion. In addition, fetuin-A may confer these protective effects through other alternative mechanisms. For instance, fetuin-A may be capable of binding bacteria [130,131], thereby affecting macrophage-mediated pathogen elimination. Furthermore, fetuin-A may facilitate macrophage-mediated ingestion and elimination of apoptotic neutrophils [132,133], thereby preventing secondary necrosis and passive leakage of injurious molecules (e.g., proteases, reactive oxygen species, and HMGB1) [134].

\section{CONCLUSIONS}

The hepatic fetuin-A expression may be divergently regulated by different proinflammatory mediators - inhibited by TNF and IFN- $\gamma$, but stimulated by HMGB1. As a positive or negative APP, fetuin-A counter-regulates both injury- and infection-elicited inflammatory responses. Consistent with the transient changes of the blood-brain barrier permeability, fetuin-A gains temporal entry into the ischemic brain tissue, and confers a short-term neuroprotective effects. In contrast, administration of fetuin-A confers a dose-dependent and long-lasting protection against lethal systemic inflammatory diseases. It is thus important to further explore its therapeutic potential for the clinical management of sepsis and other inflammatory diseases.

\section{Acknowledgments}

Work in the author's laboratory was supported by the National Institute of General Medical Sciences (R01GM063075 and R01GM070817 to HW) and the National Center of Complementary \& Alternative Medicine (R01AT05076 to HW).

\section{References}

1. Brightbill HD, Libraty DH, Krutzik SR, Yang RB, Belisle JT, Bleharski JR, Maitland M, Norgard MV, Plevy SE, Smale ST, Brennan PJ, Bloom BR, Godowski PJ, Modlin RL. Host defense mechanisms triggered by microbial lipoproteins through toll-like receptors. Science. 1999; 285(5428):732-736. [PubMed: 10426995]

2. Poltorak A, He X, Smirnova I, Liu MY, Huffel CV, Du X, Birdwell D, Alejos E, Silva M, Galanos C, Freudenberg M, Ricciardi-Castagnoli P, Layton B, Beutler B. Defective LPS signaling in C3H/ HeJ and C57BL/10ScCr mice: mutations in Tlr4 gene. Science. 1998; 282(5396):2085-2088. [PubMed: 9851930]

3. Hemmi H, Takeuchi O, Kawai T, Kaisho T, Sato S, Sanjo H, Matsumoto M, Hoshino K, Wagner H, Takeda K, Akira S. A Toll-like receptor recognizes bacterial DNA. Nature. 2000; 408(6813):740745. [PubMed: 11130078]

4. Andersson U, Wang H, Palmblad K, Aveberger AC, Bloom O, Erlandsson-Harris H, Janson A, Kokkola R, Zhang M, Yang H, Tracey KJ. High Mobility Group 1 Protein (HMG-1) Stimulates Proinflammatory Cytokine Synthesis in Human Monocytes. J Exp Med. 2000; 192(4):565-570. [PubMed: 10952726]

5. Chen GY, Tang J, Zheng P, Liu Y. CD24 and Siglec-10 selectively repress tissue damage-induced immune responses. Science. 2009; 323(5922):1722-1725. [PubMed: 19264983] 
6. Krieg AM. CpG motifs in bacterial DNA and their immune effects. Annu Rev Immunol. 2002; 20:709-760. [PubMed: 11861616]

7. Wang H, Bloom O, Zhang M, Vishnubhakat JM, Ombrellino M, Che J, Frazier A, Yang H, Ivanova S, Borovikova L, Manogue KR, Faist E, Abraham E, Andersson J, Andersson U, Molina PE, Abumrad NN, Sama A, Tracey KJ. HMG-1 as a late mediator of endotoxin lethality in mice. Science. 1999; 285(5425):248-251. [PubMed: 10398600]

8. Tracey KJ, Fong Y, Hesse DG, Manogue KR, Lee AT, Kuo GC, Lowry SF, Cerami A. Anticachectin/TNF monoclonal antibodies prevent septic shock during lethal bacteraemia. Nature. 1987; 330(6149):662-664. [PubMed: 3317066]

9. Dinarello CA, Thompson RC. Blocking IL-1: interleukin 1 receptor antagonist in vivo and in vitro. Immunol Today. 1991; 12(11):404-410. [PubMed: 1838480]

10. Heinzel FP. The role of IFN-gamma in the pathology of experimental endotoxemia. J Immunol. 1990; 145(9):2920-2924. [PubMed: 2120341]

11. Ivanov S, Dragoi AM, Wang X, Dallacosta C, Louten J, Musco G, Sitia G, Yap GS, Wan Y, Biron CA, Bianchi ME, Wang H, Chu WM. A novel role for HMGB1 in TLR9-mediated inflammatory responses to CpG-DNA. Blood. 2007; 110(6):1970-1981. [PubMed: 17548579]

12. Rendon-Mitchell B, Ochani M, Li J, Han J, Wang H, Yang H, Susarla S, Czura C, Mitchell RA, Chen G, Sama AE, Tracey KJ, Wang H. IFN-gamma Induces High Mobility Group Box 1 Protein Release Partly Through a TNF-Dependent Mechanism. J Immunol. 2003; 170(7):3890-3897. [PubMed: 12646658]

13. Scaffidi P, Misteli T, Bianchi ME. Release of chromatin protein HMGB1 by necrotic cells triggers inflammation. Nature. 2002; 418(6894):191-195. [PubMed: 12110890]

14. Cohen MJ, Brohi K, Calfee CS, Rahn P, Chesebro BB, Christiaans SC, Carles M, Howard M, Pittet JF. Early release of high mobility group box nuclear protein 1 after severe trauma in humans: role of injury severity and tissue hypoperfusion. Crit Care. 2009; 13(6):R174. [PubMed: 19887013]

15. Park JS, Svetkauskaite D, He Q, Kim JY, Strassheim D, Ishizaka A, Abraham E. Involvement of TLR 2 and TLR 4 in cellular activation by high mobility group box 1 protein (HMGB1). J Biol Chem. 2004; 279(9):7370-7377. [PubMed: 14660645]

16. Yu M, Wang H, Ding A, Golenbock DT, Latz E, Czura CJ, Fenton MJ, Tracey KJ, Yang H. HMGB1 SIGNALS THROUGH TOLL-LIKE RECEPTOR (TLR) 4 AND TLR2. Shock. 2006; 26(2):174-179. [PubMed: 16878026]

17. Dai S, Sodhi C, Cetin S, Richardson W, Branca M, Neal MD, Prindle T, Ma C, Shapiro RA, Li B, Wang JH, Hackam DJ. Extracellular high mobility group box-1 (HMGB1) inhibits enterocyte migration via activation of Toll-like receptor-4 and increased cell-matrix adhesiveness. J Biol Chem. 2010; 285(7):4995-5002. [PubMed: 20007974]

18. Park JS, Gamboni-Robertson F, He Q, Svetkauskaite D, Kim JY, Strassheim D, Sohn JW, Yamada S, Maruyama I, Banerjee A, Ishizaka A, Abraham E. High mobility group box 1 protein interacts with multiple Toll-like receptors. Am J Physiol Cell Physiol. 2006; 290(3):C917-C924. [PubMed: 16267105]

19. Kokkola R, Andersson A, Mullins G, Ostberg T, Treutiger CJ, Arnold B, Nawroth P, Andersson U, Harris RA, Harris HE. RAGE is the Major Receptor for the Proinflammatory Activity of HMGB1 in Rodent Macrophages. Scand J Immunol. 2005; 61(1):1-9. [PubMed: 15644117]

20. Pedrazzi M, Patrone M, Passalacqua M, Ranzato E, Colamassaro D, Sparatore B, Pontremoli S, Melloni E. Selective proinflammatory activation of astrocytes by high-mobility group box 1 protein signaling. J Immunol. 2007; 179(12):8525-8532. [PubMed: 18056400]

21. Yamoah K, Brebene A, Baliram R, Inagaki K, Dolios G, Arabi A, Majeed R, Amano H, Wang R, Yanagisawa R, Abe E. High-mobility group box proteins modulate tumor necrosis factor-alpha expression in osteoclastogenesis via a novel deoxyribonucleic acid sequence. Mol Endocrinol. 2008; 22(5):1141-1153. [PubMed: 18218727]

22. Fiuza C, Bustin M, Talwar S, Tropea M, Gerstenberger E, Shelhamer JH, Suffredini AF. Inflammation-promoting activity of HMGB1 on human microvascular endothelial cells. Blood. 2003; 101(7):2652-2660. [PubMed: 12456506] 
23. Treutiger CJ, Mullins GE, Johansson AS, Rouhiainen A, Rauvala HM, Erlandsson-Harris H, Andersson U, Yang H, Tracey KJ, Andersson J, Palmblad JE. High mobility group 1 B-box mediates activation of human endothelium. J Intern Med. 2003; 254(4):375-385. [PubMed: 12974876]

24. Lv B, Wang H, Tang Y, Fan Z, Xiao X, Chen F. High-mobility group box 1 protein induces tissue factor expression in vascular endothelial cells via activation of NF-kappaB and Egr-1. Thromb Haemost. 2009; 102(2):352-359. [PubMed: 19652887]

25. Yang D, Chen Q, Yang H, Tracey KJ, Bustin M, Oppenheim JJ. High mobility group box-1 protein induces the migration and activation of human dendritic cells and acts as an alarmin. J Leukoc Biol. 2007; 81(1):59-66. [PubMed: 16966386]

26. Dumitriu IE, Bianchi ME, Bacci M, Manfredi AA, Rovere-Querini P. The secretion of HMGB1 is required for the migration of maturing dendritic cells. J Leukoc Biol. 2007; 81(1):84-91. [PubMed: 17035340]

27. Orlova VV, Choi EY, Xie C, Chavakis E, Bierhaus A, Ihanus E, Ballantyne CM, Gahmberg CG, Bianchi ME, Nawroth PP, Chavakis T. A novel pathway of HMGB1-mediated inflammatory cell recruitment that requires Mac-1-integrin. EMBO J. 2007; 26(4):1129-1139. [PubMed: 17268551]

28. Zhu S, Ashok M, Li J, Li W, Yang H, Wang P, Tracey KJ, Sama AE, Wang H. Spermine protects mice against lethal sepsis partly by attenuating surrogate inflammatory markers. Mol Med. 2009; 15(7-8):275-282. [PubMed: 19593412]

29. Yang H, Ochani M, Li J, Qiang X, Tanovic M, Harris HE, Susarla SM, Ulloa L, Wang H, DiRaimo R, Czura CJ, Wang H, Roth J, Warren HS, Fink MP, Fenton MJ, Andersson U, Tracey KJ. Reversing established sepsis with antagonists of endogenous high-mobility group box 1. Proc Natl Acad Sci U S A. 2004; 101(1):296-301. [PubMed: 14695889]

30. Wang H, Yang H, Czura CJ, Sama AE, Tracey KJ. HMGB1 as a Late Mediator of Lethal Systemic Inflammation. Am J Respir Crit Care Med. 2001; 164(10):1768-1773. [PubMed: 11734424]

31. Qin S, Wang H, Yuan R, Li H, Ochani M, Ochani K, Rosas-Ballina M, Czura CJ, Huston JM, Miller E, Lin X, Sherry B, Kumar A, Larosa G, Newman W, Tracey KJ, Yang H. Role of HMGB1 in apoptosis-mediated sepsis lethality. J Exp Med. 2006; 203(7):1637-1642. [PubMed: 16818669]

32. Ulloa L, Ochani M, Yang H, Tanovic M, Halperin D, Yang R, Czura CJ, Fink MP, Tracey KJ. Ethyl pyruvate prevents lethality in mice with established lethal sepsis and systemic inflammation. Proc Natl Acad Sci U S A. 2002; 99(19):12351-12356. [PubMed: 12209006]

33. Chen G, Li J, Qiang X, Czura CJ, Ochani M, Ochani K, Ulloa L, Yang H, Tracey KJ, Wang P, Sama AE, Wang H. Suppression of HMGB1 release by stearoyl lysophosphatidylcholine:an additional mechanism for its therapeutic effects in experimental sepsis. J Lipid Res. 2005; 46(4): 623-627. [PubMed: 15687351]

34. Wang H, Li W, Li J, Rendon-Mitchell B, Ochani M, Ashok M, Yang L, Yang H, Tracey KJ, Wang P, Sama AE. The Aqueous Extract of a Popular Herbal Nutrient Supplement, Angelica sinensis, Protects Mice against Lethal Endotoxemia and Sepsis. J Nutr. 2006; 136(2):360-365. [PubMed: 16424112]

35. Li W, Ashok M, Li J, Yang H, Sama AE, Wang H. A Major Ingredient of Green Tea Rescues Mice from Lethal Sepsis Partly by Inhibiting HMGB1. PLoS ONE. 2007; 2(11):e1153. [PubMed: 17987129]

36. Wang H, Liao H, Ochani M, Justiniani M, Lin X, Yang L, Al Abed Y, Wang H, Metz C, Miller EJ, Tracey KJ, Ulloa L. Cholinergic agonists inhibit HMGB1 release and improve survival in experimental sepsis. Nat Med. 2004; 10(11):1216-1221. [PubMed: 15502843]

37. Wang H, Czura CJ, Tracey KJ. Lipid unites disparate syndromes of sepsis. Nat Med. 2004; 10(2): 124-125. [PubMed: 14760415]

38. Pavlov VA, Ochani M, Yang LH, Gallowitsch-Puerta M, Ochani K, Lin X, Levi J, Parrish WR, Rosas-Ballina M, Czura CJ, Larosa GJ, Miller EJ, Tracey KJ, Al Abed Y. Selective alpha7nicotinic acetylcholine receptor agonist GTS-21 improves survival in murine endotoxemia and severe sepsis. Crit Care Med. 2007; 35(4):1139-1144. [PubMed: 17334244]

39. Parrish WR, Rosas-Ballina M, Gallowitsch-Puerta M, Ochani M, Ochani K, Yang LH, Hudson L, Lin X, Patel N, Johnson SM, Chavan S, Goldstein RS, Czura CJ, Miller EJ, Al Abed Y, Tracey KJ, Pavlov VA. Modulation of TNF release by choline requires alpha7 subunit nicotinic 
acetylcholine receptor-mediated signaling. Mol Med. 2008; 14(9-10):567-574. [PubMed: 18584048]

40. Matthay MA, Ware LB. Can nicotine treat sepsis? Nat Med. 2004; 10(11):1161-1162. [PubMed: 15516907]

41. O’Connor KA, Hansen MK, Rachal PC, Deak MM, Biedenkapp JC, Milligan ED, Johnson JD, Wang H, Maier SF, Tracey KJ, Watkins LR. Further characterization of high mobility group box 1 (HMGB1) as a proinflammatory cytokine: central nervous system effects. Cytokine. 2003; 24(6): 254-265. [PubMed: 14609567]

42. Sappington PL, Yang R, Yang H, Tracey KJ, Delude RL, Fink MP. HMGB1 B box increases the permeability of Caco-2 enterocytic monolayers and impairs intestinal barrier function in mice. Gastroenterology. 2002; 123(3):790-802. [PubMed: 12198705]

43. Abraham E, Arcaroli J, Carmody A, Wang H, Tracey KJ. HMG-1 as a mediator of acute lung inflammation. J Immunol. 2000; 165(6):2950-2954. [PubMed: 10975801]

44. Ueno H, Matsuda T, Hashimoto S, Amaya F, Kitamura Y, Tanaka M, Kobayashi A, Maruyama I, Yamada S, Hasegawa N, Soejima J, Koh H, Ishizaka A. Contributions of high mobility group box protein in experimental and clinical acute lung injury. Am J Respir Crit Care Med. 2004; 170(12): 1310-1316. [PubMed: 15374839]

45. Lin X, Yang H, Sakuragi T, Hu M, Mantell LL, Hayashi S, Al Abed Y, Tracey KJ, Ulloa L, Miller EJ. \{alpha\}-Chemokine receptor blockade reduces high mobility group box 1 protein-induced lung inflammation and injury and improves survival in sepsis. Am J Physiol Lung Cell Mol Physiol. 2005; 289(4):L583-L590. [PubMed: 15937067]

46. Rowe SM, Jackson PL, Liu G, Hardison M, Livraghi A, Solomon GM, McQuaid DB, Noerager BD, Gaggar A, Clancy J, O’Neal W, Sorscher EJ, Abraham E, Blalock JE. Potential Role of High Mobility Group Box 1 in Cystic Fibrosis Airway Disease. Am J Respir Crit Care Med. 2008

47. Wang H, Yang H, Tracey KJ. Extracellular role of HMGB1 in inflammation and sepsis. J Intern Med. 2004; 255(3):320-331. [PubMed: 14871456]

48. Wang H, Zhu S, Zhou R, Li W, Sama AE. Therapeutic potential of HMGB1-targeting agents in sepsis. Expert Rev Mol Med. 2008; 10:e32. [PubMed: 18980707]

49. Wang H, Ward MF, Sama AE. Novel HMGB1-inhibiting therapeutic agents for experimental sepsis. Shock. 2009; 32(4):348-357. [PubMed: 19333143]

50. Taylor CP, Meldrum BS. Na+ channels as targets for neuroprotective drugs. Trends Pharmacol Sci. 1995; 16(9):309-316. [PubMed: 7482996]

51. Lee JM, Zipfel GJ, Choi DW. The changing landscape of ischaemic brain injury mechanisms. Nature. 1999; 399(Supplement):A7-A14. [PubMed: 10392575]

52. Feuerstein GZ, Wang X, Barone FC. The role of cytokines in the neuropathology of stroke and neurotrauma. Neuroimmunomodulation. 1998; 5(3-4):143-159. [PubMed: 9730680]

53. Meldrum B. Protection against ischaemic neuronal damage by drugs acting on excitatory neurotransmission. Cerebrovasc Brain Metab Rev. 1990; 2(1):27-57. [PubMed: 2169834]

54. Kato H, Kogure K, Liu XH, Araki T, Itoyama Y. Progressive expression of immunomolecules on activated microglia and invading leukocytes following focal cerebral ischemia in the rat. Brain Res. 1996; 734(1-2):203-212. [PubMed: 8896826]

55. Botchkina GI, Meistrell ME, Botchkina IL, Tracey KJ. Expression of TNF and TNF receptors (p55 and p75) in the rat brain after focal cerebral ischemia. Mol Med. 1997; 3(11):765-781. [PubMed: 9407552]

56. Akopov SE, Simonian NA, Grigorian GS. Dynamics of polymorphonuclear leukocyte accumulation in acute cerebral infarction and their correlation with brain tissue damage. Stroke. 1996; 27(10):1739-1743. [PubMed: 8841321]

57. Buttini M, Appel K, Sauter A, Gebicke-Haerter PJ, Boddeke HW. Expression of tumor necrosis factor alpha after focal cerebral ischaemia in the rat. Neuroscience. 1996; 71(1):1-16. [PubMed: 8834388]

58. Zaremba J, Losy J. Early TNF-alpha levels correlate with ischaemic stroke severity. Acta Neurol Scand. 2001 Nov; 104(5):288-295. [PubMed: 11696023] 
59. Meistrell ME, Botchkina GI, Wang H, Di Santo E, Cockroft KM, Bloom O, Vishnubhakat JM, Ghezzi P, Tracey KJ. Tumor necrosis factor is a brain damaging cytokine in cerebral ischemia. Shock. 1997; 8(5):341-348. [PubMed: 9361344]

60. Bertorelli R, Adami M, Di Santo E, Ghezzi P. MK 801 and dexamethasone reduce both tumor necrosis factor levels and infarct volume after focal cerebral ischemia in the rat brain. Neurosci Lett. 1998; 246(1):41-44. [PubMed: 9622203]

61. Barone FC, Arvin B, White RF, Miller A, Webb CL, Willette RN, Lysko PG, Feuerstein GZ. Tumor necrosis factor-alpha. A mediator of focal ischemic brain injury. Stroke. 1997; 28(6):12331244. [PubMed: 9183357]

62. Yang GY, Gong C, Qin Z, Liu XH, Lorris BA. Tumor necrosis factor alpha expression produces increased blood-brain barrier permeability following temporary focal cerebral ischemia in mice. Brain Res Mol Brain Res. 1999; 69(1):135-143. [PubMed: 10350645]

63. Qiu J, Nishimura M, Wang Y, Sims JR, Qiu S, Savitz SI, Salomone S, Moskowitz MA. Early release of HMGB-1 from neurons after the onset of brain ischemia. J Cereb Blood Flow Metab. 2008; 28(5):927-938. [PubMed: 18000511]

64. Zhang J, Takahashi HK, Liu K, Wake H, Liu R, Maruo T, Date I, Yoshino T, Ohtsuka A, Mori S, Nishibori M. Anti-high mobility group box-1 monoclonal antibody protects the blood-brain barrier from ischemia-induced disruption in rats. Stroke. 2011; 42(5):1420-1428. [PubMed: 21474801]

65. Yang QW, Lu FL, Zhou Y, Wang L, Zhong Q, Lin S, Xiang J, Li JC, Fang CQ, Wang JZ. HMBG1 mediates ischemia-reperfusion injury by TRIF-adaptor independent Toll-like receptor 4 signaling. J Cereb Blood Flow Metab. 2011; 31(2):593-605. [PubMed: 20700129]

66. Muhammad S, Barakat W, Stoyanov S, Murikinati S, Yang H, Tracey KJ, Bendszus M, Rossetti G, Nawroth PP, Bierhaus A, Schwaninger M. The HMGB1 receptor RAGE mediates ischemic brain damage. J Neurosci. 2008; 28(46):12023-12031. [PubMed: 19005067]

67. Rosas-Ballina M, Olofsson PS, Ochani M, Valdes-Ferrer SI, Levine YA, Reardon C, Tusche MW, Pavlov VA, Andersson U, Chavan S, Mak TW, Tracey KJ. Acetylcholine-synthesizing T cells relay neural signals in a vagus nerve circuit. Science. 2011; 334(6052):98-101. [PubMed: 21921156]

68. Borovikova LV, Ivanova S, Zhang M, Yang H, Botchkina GI, Watkins LR, Wang H, Abumrad N, Eaton JW, Tracey KJ. Vagus nerve stimulation attenuates the systemic inflammatory response to endotoxin. Nature. 2000; 405(6785):458-462. [PubMed: 10839541]

69. Wang H, Yu M, Ochani M, Amella CA, Tanovic M, Susarla S, Li JH, Wang H, Yang H, Ulloa L, Al Abed Y, Czura CJ, Tracey KJ. Nicotinic acetylcholine receptor alpha7 subunit is an essential regulator of inflammation. Nature. 2003; 421(6921):384-388. [PubMed: 12508119]

70. Huston JM, Gallowitsch-Puerta M, Ochani M, Ochani K, Yuan R, Rosas-Ballina M, Ashok M, Goldstein RS, Chavan S, Pavlov VA, Metz CN, Yang H, Czura CJ, Wang H, Tracey KJ. Transcutaneous vagus nerve stimulation reduces serum high mobility group box 1 levels and improves survival in murine sepsis. Crit Care Med. 2007; 35(12):2762-2768. [PubMed: 17901837]

71. Su X, Matthay MA, Malik AB. Requisite role of the cholinergic alpha7 nicotinic acetylcholine receptor pathway in suppressing Gram-negative sepsis-induced acute lung inflammatory injury. J Immunol. 2010; 184(1):401-410. [PubMed: 19949071]

72. Oswald IP, Wynn TA, Sher A, James SL. Interleukin 10 inhibits macrophage microbicidal activity by blocking the endogenous production of tumor necrosis factor alpha required as a costimulatory factor for interferon gamma-induced activation. Proc Natl Acad Sci U S A. 1992; 89(18):86768680. [PubMed: 1528880]

73. Bogdan C, Vodovotz Y, Nathan C. Macrophage deactivation by interleukin 10. J Exp Med. 1991; 174(6):1549-1555. [PubMed: 1744584]

74. Hart PH, Vitti GF, Burgess DR, Whitty GA, Piccoli DS, Hamilton JA. Potential antiinflammatory effects of interleukin 4: suppression of human monocyte tumor necrosis factor alpha, interleukin 1, and prostaglandin E2. Proc Natl Acad Sci U S A. 1989; 86(10):3803-3807. [PubMed: 2786204]

75. Paschen W. Polyamine metabolism in reversible cerebral ischemia. Cerebrovasc Brain Metab Rev. 1992; 4(1):59-88. [PubMed: 1562452] 
76. Zhang M, Caragine T, Wang H, Cohen PS, Botchkina G, Soda K, Bianchi M, Ulrich P, Cerami A, Sherry B, Tracey KJ. Spermine inhibits proinflammatory cytokine synthesis in human mononuclear cells: a counterregulatory mechanism that restrains the immune response. J Exp Med. 1997; 185(10):1759-1768. [PubMed: 9151701]

77. Zhang M, Borovikova LV, Wang H, Metz C, Tracey KJ. Spermine inhibition of monocyte activation and inflammation. Mol Med. 1999; 5(9):595-605. [PubMed: 10551901]

78. Wang H, Zhang M, Bianchi M, Sherry B, Sama A, Tracey KJ. Fetuin (alpha2-HS-glycoprotein) opsonizes cationic macrophagedeactivating molecules. Proc Natl Acad Sci U S A. 1998; 95(24): 14429-14434. [PubMed: 9826717]

79. Zhang M, Wang H, Tracey KJ. Regulation of macrophage activation and inflammation by spermine: a new chapter in an old story. Crit Care Med. 2000; 28(4 Suppl):N60-N66. [PubMed: 10807317]

80. Wang H, Zhang M, Soda K, Sama A, Tracey KJ. Fetuin protects the fetus from TNF [letter]. Lancet. 1997; 350(9081):861-862. [PubMed: 9310607]

81. Wang, H.; Tracey, KJ. Fetuin opsonizes macrophage-deactivating cations. In: Marshall, JC.; Cohen, J., editors. Update in Intensive Care and Emergency Medicine: Immune Response in the Critically Ill. SpringerVerlag Press; 1999. p. 155-163.

82. Christie DL, Dziegielewska KM, Hill RM, Saunders NR. Fetuin: the bovine homologue of human alpha 2HS glycoprotein. FEBS Lett. 1987; 214(1):45-49. [PubMed: 2436943]

83. Pedersen KO. Fetuin, a new globin isolated from serum. Nature. 1944; 154:575-570.

84. Terkelsen OB, Jahnen-Dechent W, Nielsen H, Moos T, Fink E, Nawratil P, Muller-Esterl W, Mollgard K. Rat fetuin: distribution of protein and mRNA in embryonic and neonatal rat tissues. Anat Embryol (Berl). 1998; 197(2):125-133. [PubMed: 9497155]

85. Kitchener PD, Dziegielewska KM, Knott GW, Miller JM, Nawratil P, Potter AE, Saunders NR. Fetuin expression in the dorsal root ganglia and trigeminal ganglia of perinatal rats. Int J Dev Neurosci. 1997; 15(6):717-727. [PubMed: 9402222]

86. Dziegielewska KM, Daikuhara Y, Ohnishi T, Waite MP, Ek J, Habgood MD, Lane MA, Potter A, Saunders NR. Fetuin in the developing neocortex of the rat: distribution and origin. J Comp Neurol. 2000; 423(3):373-388. [PubMed: 10870079]

87. Kitchener PD, Dziegielewska KM, Hutton EJ, Hinrichsen CF, Saunders NR. Fetuin in neurons of the retina and cerebellum during fetal and postnatal development of the rat. Int J Dev Neurosci. 1999; 17(1):21-30. [PubMed: 10219957]

88. Daveau M, Christian D, Julen N, Hiron M, Arnaud P, Lebreton JP. The synthesis of human alpha-2-HS glycoprotein is down-regulated by cytokines in hepatoma HepG2 cells. FEBS Lett. 1988; 241(1-2):191-194. [PubMed: 2848721]

89. Li W, Zhu S, Li J, Huang Y, Zhou R, Fan X, Yang H, Gong X, Eissa NT, Jahnen-Dechent W, Wang P, Tracey KJ, Sama AE, Wang H. A hepatic protein, fetuin-A, occupies a protective role in lethal systemic inflammation. PLoS ONE. 2011; 6(2):e16945. [PubMed: 21347455]

90. Kusnierz-Cabala B, Gurda-Duda A, Panek J, Fedak D, Dumnicka P, Solnica B, Kulig J. Serum fetuin A concentrations in patients with acute pancreatitis. Clin Lab. 2010; 56(5-6):191-195. [PubMed: 20575466]

91. Metry G, Stenvinkel P, Qureshi AR, Carrero JJ, Yilmaz MI, Barany P, Snaedal S, Heimburger O, Lindholm B, Suliman ME. Low serum fetuin-A concentration predicts poor outcome only in the presence of inflammation in prevalent haemodialysis patients. Eur J Clin Invest. 2008; 38(11): 804-811. [PubMed: 19021697]

92. Sato H, Kazama JJ, Wada Y, Kuroda T, Narita I, Gejyo F, Gao P, Yamashita H. Decreased levels of circulating alpha2-Heremans-Schmid glycoprotein/Fetuin-A (AHSG) in patients with rheumatoid arthritis. Intern Med. 2007; 46(20):1685-1691. [PubMed: 17938521]

93. Weikert C, Stefan N, Schulze MB, Pischon T, Berger K, Joost HG, Haring HU, Boeing H, Fritsche A. Plasma fetuin-a levels and the risk of myocardial infarction and ischemic stroke. Circulation. 2008; 118(24):2555-2562. [PubMed: 19029462]

94. Tuttolomondo A, Di Raimondo D, Di Sciacca R, Casuccio A, Bivona G, Bellia C, Barreca L, Serio A, D’Aguanno G, Ciaccio M, Licata G, Pinto A. Fetuin-A and CD40 L plasma levels in acute 
ischemic stroke: Differences in relation to TOAST subtype and correlation with clinical and laboratory variables. Atherosclerosis. 2010; 208(1):290-296. [PubMed: 19709661]

95. Dziegielewska KM, Brown WM, Gould CC, Matthews N, Sedgwick JE, Saunders NR. Fetuin: an acute phase protein in cattle. J Comp Physiol [B]. 1992; 162(2):168-171.

96. Peltz ED, Moore EE, Eckels PC, Damle SS, Tsuruta Y, Johnson JL, Sauaia A, Silliman CC, Banerjee A, Abraham E. HMGB1 is markedly elevated within 6 hours of mechanical trauma in humans. Shock. 2009; 32(1):17-22. [PubMed: 19533845]

97. Zhu S, Li W, Ward MF, Sama AE, Wang H. High mobility group box 1 protein as a potential drug target for infection- and injury-elicited inflammation. Inflamm Allergy Drug Targets. 2010; 9(1): 60-72. [PubMed: 19906009]

98. Wu H, Chen G, Wyburn KR, Yin J, Bertolino P, Eris JM, Alexander SI, Sharland AF, Chadban SJ. TLR4 activation mediates kidney ischemia/reperfusion injury. J Clin Invest. 2007; 117(10):2847_ 2859. [PubMed: 17853945]

99. Tsung A, Sahai R, Tanaka H, Nakao A, Fink MP, Lotze MT, Yang H, Li J, Tracey KJ, Geller DA, Billiar TR. The nuclear factor HMGB1 mediates hepatic injury after murine liver ischemiareperfusion. J Exp Med. 2005; 201(7):1135-1143. [PubMed: 15795240]

100. Tsung A, Klune JR, Zhang X, Jeyabalan G, Cao Z, Peng X, Stolz DB, Geller DA, Rosengart MR, Billiar TR. HMGB1 release induced by liver ischemia involves Toll-like receptor 4 dependent reactive oxygen species production and calcium-mediated signaling. J Exp Med. 2007; 204(12): 2913-2923. [PubMed: 17984303]

101. Watanabe T, Kubota S, Nagaya M, Ozaki S, Nagafuchi H, Akashi K, Taira Y, Tsukikawa S, Oowada S, Nakano S. The role of HMGB-1 on the development of necrosis during hepatic ischemia and hepatic ischemia/reperfusion injury in mice. J Surg Res. 2005; 124(1):59-66. [PubMed: 15734480]

102. Wang H, Li W, Zhu S, Li J, D’Amore J, Ward MF, Yang H, Wu R, Jahnen-Dechent W, Tracey KJ, Wang P, Sama AE. Peripheral administration of fetuin-A attenuates early cerebral ischemic injury in rats. J Cereb Blood Flow Metab. 2010; 30(3):493-504. [PubMed: 19953099]

103. Belayev L, Busto R, Zhao W, Ginsberg MD. Quantitative evaluation of blood-brain barrier permeability following middle cerebral artery occlusion in rats. Brain Res. 1996; 739(1-2):8896. [PubMed: 8955928]

104. Demetriou M, Binkert C, Sukhu B, Tenenbaum HC, Dennis JW. Fetuin/alpha2-HS glycoprotein is a transforming growth factor-beta type II receptor mimic and cytokine antagonist. J Biol Chem. 1996; 271(22):12755-12761. [PubMed: 8662721]

105. Mathews ST, Srinivas PR, Leon MA, Grunberger G. Bovine fetuin is an inhibitor of insulin receptor tyrosine kinase. Life Sci. 1997; 61(16):1583-1592. [PubMed: 9353167]

106. Haasemann M, Nawratil P, Muller-Esterl W. Rat tyrosine kinase inhibitor shows sequence similarity to human alpha 2-HS glycoprotein and bovine fetuin. Biochem J. 1991; 274(Pt 3):899902. [PubMed: 1707273]

107. Goustin AS, Abou-Samra AB. The "thrifty" gene encoding Ahsg/Fetuin-A meets the insulin receptor: Insights into the mechanism of insulin resistance. Cell Signal. 2010

108. Ix JH, Wassel CL, Kanaya AM, Vittinghoff E, Johnson KC, Koster A, Cauley JA, Harris TB, Cummings SR, Shlipak MG. Fetuin-A and incident diabetes mellitus in older persons. JAMA. 2008; 300(2):182-188. [PubMed: 18612115]

109. Szweras M, Liu D, Partridge EA, Pawling J, Sukhu B, Clokie C, Jahnen-Dechent W, Tenenbaum HC, Swallow CJ, Grynpas MD, Dennis JW. alpha 2-HS glycoprotein/fetuin, a transforming growth factor-beta/bone morphogenetic protein antagonist, regulates postnatal bone growth and remodeling. J Biol Chem. 2002; 277(22):19991-19997. [PubMed: 11901155]

110. Schafer C, Heiss A, Schwarz A, Westenfeld R, Ketteler M, Floege J, Muller-Esterl W, Schinke T, Jahnen-Dechent W. The serum protein alpha 2-Heremans-Schmid glycoprotein/fetuin-A is a systemically acting inhibitor of ectopic calcification. J Clin Invest. 2003; 112(3):357-366. [PubMed: 12897203]

111. Ketteler M, Bongartz P, Westenfeld R, Wildberger JE, Mahnken AH, Bohm R, Metzger T, Wanner C, Jahnen-Dechent W, Floege J. Association of low fetuin-A (AHSG) concentrations in 
serum with cardiovascular mortality in patients on dialysis: a cross-sectional study. Lancet. 2003; 361(9360):827-833. [PubMed: 12642050]

112. Jahnen-Dechent W, Heiss A, Schafer C, Ketteler M. Fetuin-A regulation of calcified matrix metabolism. Circ Res. 2011; 108(12):1494-1509. [PubMed: 21659653]

113. Heiss A, DuChesne A, Denecke B, Grotzinger J, Yamamoto K, Renne T, Jahnen-Dechent W. Structural basis of calcification inhibition by alpha 2-HS glycoprotein/fetuin-A. Formation of colloidal calciprotein particles. J Biol Chem. 2003; 278(15):13333-13341. [PubMed: 12556469]

114. Wu CY, Martel J, Young D, Young JD. Fetuin-A/albumin-mineral complexes resembling serum calcium granules and putative nanobacteria: demonstration of a dual inhibition-seeding concept. PLoS One. 2009; 4(11):e8058. [PubMed: 19956594]

115. Rochette CN, Rosenfeldt S, Heiss A, Narayanan T, Ballauff M, Jahnen-Dechent W. A shielding topology stabilizes the early stage protein-mineral complexes of fetuin-A and calcium phosphate: a time-resolved small-angle X-ray study. Chembiochem. 2009; 10(4):735-740. [PubMed: 19222044]

116. Wang, H.; Li, W.; Zhu, S.; Wang, P.; Sama, AE. Acute Phase Proteins: Regulation and Functions of Acute Phase Proteins. Intech Open Access Publisher; 2011. Role of Fetuin-A in Injury and Infection; p. 329-344.

117. Dziegielewska KM, Andersen NA, Saunders NR. Modification of macrophage response to lipopolysaccharide by fetuin. Immunol Lett. 1998; 60(1):31-35. [PubMed: 9541460]

118. Ombrellino M, Wang H, Yang H, Zhang M, Vishnubhakat J, Frazier A, Scher LA, Friedman SG, Tracey KJ. Fetuin, a negative acute phase protein, attenuates TNF synthesis and the innate inflammatory response to carrageenan. Shock. 2001; 15(3):181-185. [PubMed: 11236900]

119. Li J, Doyle KM, Tatlisumak T. Polyamines in the brain: distribution, biological interactions, and their potential therapeutic role in brain ischaemia. Curr Med Chem. 2007; 14(17):1807-1813. [PubMed: 17627518]

120. Shirhan MD, Moochhala SM, Ng PY, Lu J, Ng KC, Teo AL, Yap E, Ng I, Hwang P, Lim T, Sitoh YY, Rumpel H, Jose R, Ling E. Spermine reduces infarction and neurological deficit following a rat model of middle cerebral artery occlusion: a magnetic resonance imaging study.

Neuroscience. 2004; 124(2):299-304. [PubMed: 14980380]

121. Ha HC, Sirisoma NS, Kuppusamy P, Zweier JL, Woster PM, Casero RA Jr. The natural polyamine spermine functions directly as a free radical scavenger. Proc Natl Acad Sci U S A. 1998; 95(19):11140-11145. [PubMed: 9736703]

122. Adibhatla RM, Hatcher JF, Sailor K, Dempsey RJ. Polyamines and central nervous system injury: spermine and spermidine decrease following transient focal cerebral ischemia in spontaneously hypertensive rats. Brain Res. 2002; 938(1-2):81-86. [PubMed: 12031538]

123. Araneda RC, Lan JY, Zheng X, Zukin RS, Bennett MV. Spermine and arcaine block and permeate N-methyl-D-aspartate receptor channels. Biophys J. 1999; 76(6):2899-2911. [PubMed: 10354418]

124. Ferchmin PA, Perez D, Biello M. Spermine is neuroprotective against anoxia and N-methyl-Daspartate in hippocampal slices. Brain Res. 2000; 859(2):273-279. [PubMed: 10719074]

125. Ivanova S, Botchkina GI, Al-Abed Y, Meistrell M, Batliwalla F, Dubinsky JM, Iadecola C, Wang H, Gregersen PK, Eaton JW, Tracey KJ. Cerebral ischemia enhances polyamine oxidation: identification of enzymatically formed 3-aminopropanal as an endogenous mediator of neuronal and glial cell death. J Exp Med. 1998; 188(2):327-340. [PubMed: 9670045]

126. Williams K. Modulation and block of ion channels: a new biology of polyamines. Cell Signal. 1997; 9(1):1-13. [PubMed: 9067625]

127. Paschen W, Widmann R, Weber C. Changes in regional polyamine profiles in rat brains after transient cerebral ischemia (single versus repetitive ischemia): evidence for release of polyamines from injured neurons. Neurosci Lett. 1992; 135(1):121-124. [PubMed: 1542427]

128. Zhu S, Ashok M, Li J, Li W, Yang H, Wang P, Tracey KJ, Sama AE, Wang H. Spermine protects mice against lethal sepsis partly by attenuating surrogate inflammatory markers. Mol Med. 2009; 15(7-8):275-282. [PubMed: 19593412] 
129. Li W, Zhu S, Li J, Assa A, Jundoria A, Xu J, Fan S, Eissa NT, Tracey KJ, Sama AE, Wang H. EGCG stimulates autophagy and reduces cytoplasmic HMGB1 levels in endotoxin-stimulated macrophages. Biochem Pharmacol. 2011; 81(9):1152-1163. [PubMed: 21371444]

130. Chmiela M, Czkwianianc E, Wadstrom T, Rudnicka W. Role of Helicobacter pylori surface structures in bacterial interaction with macrophages. Gut. 1997; 40(1):20-24. [PubMed: 9155570]

131. Dubreuil JD, Giudice GD, Rappuoli R. Helicobacter pylori interactions with host serum and extracellular matrix proteins: potential role in the infectious process. Microbiol Mol Biol Rev. 2002; 66(4):617-29. [PubMed: 12456785]

132. Lord JM. A physiological role for alpha2-HS glycoprotein: stimulation of macrophage uptake of apoptotic cells. Clin Sci (Lond). 2003; 105(3):267-268. [PubMed: 12773197]

133. Jersmann HP, Dransfield I, Hart SP. Fetuin/alpha2-HS glycoprotein enhances phagocytosis of apoptotic cells and macropinocytosis by human macrophages. Clin Sci (Lond). 2003; 105(3): 273-278. [PubMed: 12725640]

134. Bell CW, Jiang W, Reich CF, Pisetsky DS. The Extracellular Release of HMGB1 during Apoptotic Cell Death. Am J Physiol Cell Physiol. 2006; 291(6):C1318-1325. [PubMed: 16855214] 


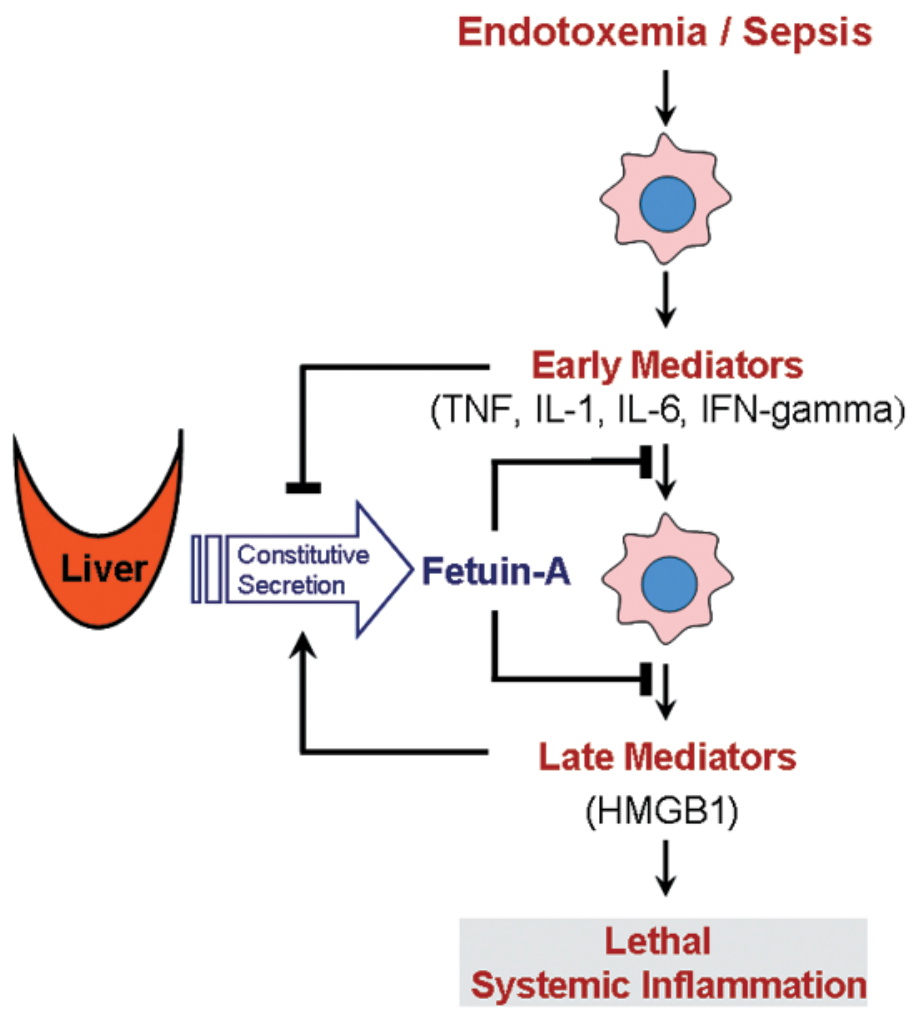

Figure 1. Protective roles of fetuin-A in endotoxemia and sepsis

In response to lethal endotoxemia or sepsis, innate immune cells (such as macrophages) sequentially release early (e.g., TNF and IFN- $\gamma$ ) and late (e.g., HMGB1) proinflammatory mediators. Early proinflammatory cytokines participate in the down-regulation of hepatic fetuin-A expression, allowing propagation of a rigorous inflammatory response manifested by excess accumulation of late proinflammatory mediators (such as HMGB1). On the other hand, HMGB1 stimulates hepatic fetuin-A expression, thereby restoring circulating fetuin-A levels during a late stage of lethal endotoxemia and sepsis. Fetuin-A functions as a negative regulator of the innate immune response by inhibiting LPS- or IFN- $\gamma$-induced HMGB1 release in macrophages. Adapted from doi:10.1371/journal.pone.0016945.g006 with granted permission from the publisher. 


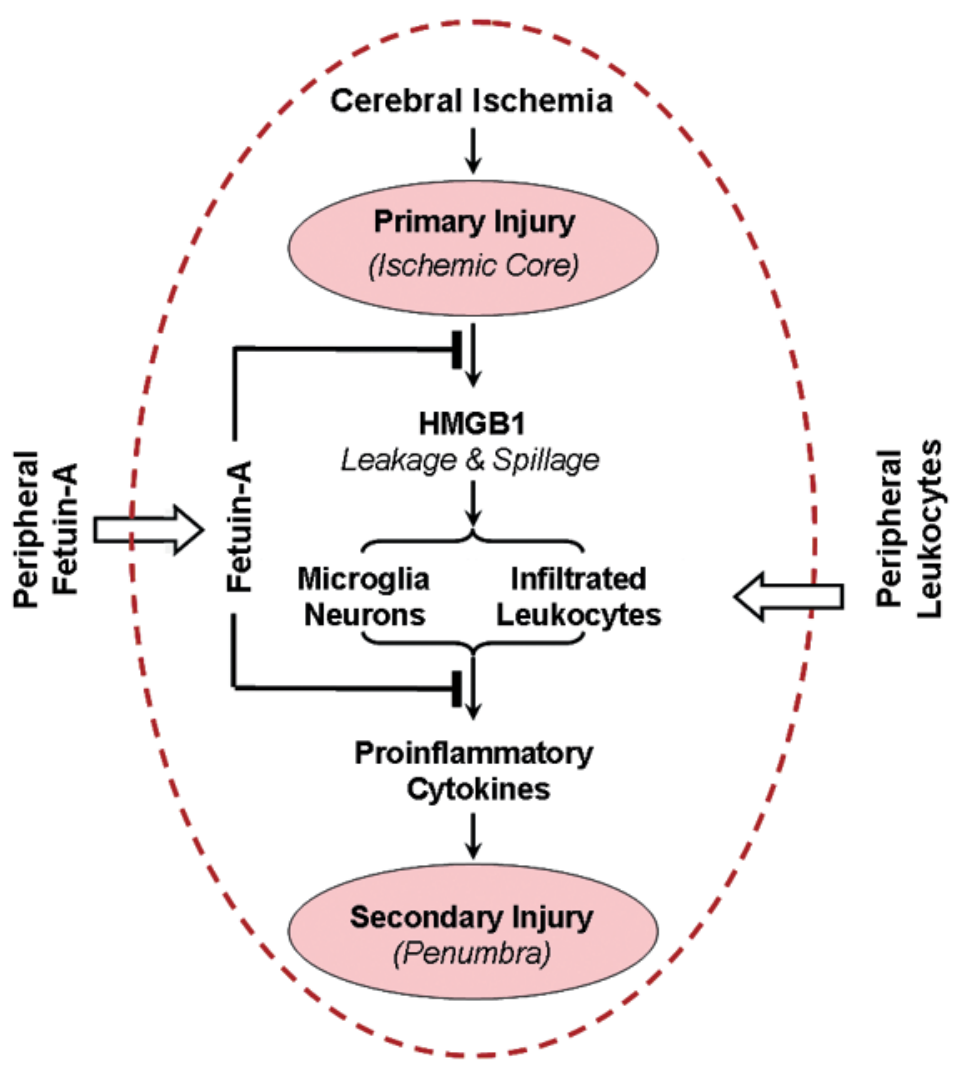

Figure 2. Protective roles of fetuin-A in cerebral ischemic injury

Cerebral ischemia causes rapid primary injury in the ischemic core, leading to HMGB1 release/leakage. Extracellular HMGB1 then diffuses into the periphery region, where it orchestrates a rigorous inflammatory response driven both by the centrally- and peripherally-derived cells. In parallel, cerebral ischemia induces transient increase in bloodbrain barrier permeability, allowing entry of circulating proteins (e.g., fetuin-A) and peripheral immune cells (such as macrophage/monocytes). Peripheral administration of fetuin-A attenuates ischemia-elicited HMGB1 release and subsequent cytokine expression, thereby conferring a temporal protection against cerebral ischemic injury. 


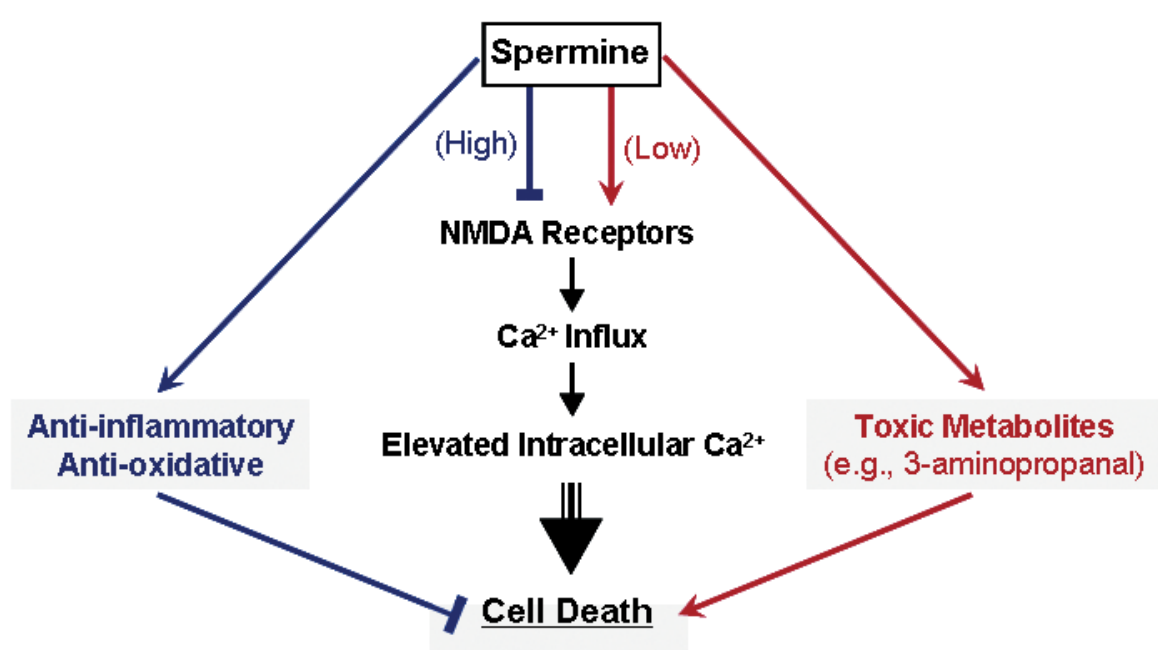

Figure 3. Divergent roles of spermine in cerebral ischemic injury 